\title{
Solid Lung Adenocarcinoma
}

National Cancer Institute

\section{Source}

National Cancer Institute. Solid Lung Adenocarcinoma. NCI Thesaurus. Code C5651.

A morphologic variant of lung adenocarcinoma characterized by the presence of polyg onal malignant cells forming sheets. Acinar, papillary, micropapillary, or lepidic growth patterns are absent. If the tumor is 100 percent solid, intracellular mucin should be present in at least five tumor cells in each of two high-power fields and confirmed with mucin immunohistochemical stains. Tumors formerly classified as large cell carcinomas expressing pneumocyte immunohistochemical markers, even if intracellular mucin is absent, are now included in this category. 